Article

\title{
Welfare Deservingness for Migrants: Does the Welfare State Model Matter?
}

\author{
Maarja Saar ${ }^{1,2, *}$, Bozena Sojka ${ }^{3}$, and Ann Runfors ${ }^{2}$ \\ ${ }^{1}$ School of Education and Communication, Jönköping University, Sweden \\ 2 Historical and Contemporary Studies, Södertörn University, Sweden \\ ${ }^{3}$ Institute for Community Research \& Development (ICRD), University of Wolverhampton, UK \\ * Corresponding author (maarjasaar@hotmail.com)
}

Submitted: 16 August 2021 | Accepted: 2 December 2021 | Published: 22 March 2022

\begin{abstract}
This article draws on the idea that welfare systems and institutions are based on normative assumptions about justice, solidarity, and responsibility. Even though the literature on welfare deservingness has highlighted the connection between ideas of solidarity and the support to, for instance, people with different ethnic backgrounds, there is very little research on the interconnections of different welfare state models and ideas on how migration should be governed. This article suggests that there is a link between the welfare state models suggested by Esping-Anderssen and different discourses on migrant welfare deservingness. The article explores the interlinkages of three welfare state models-liberal, socialdemocratic, and continental-corporative-and four discourses on welfare deservingness of migrants in respect to social welfare-labourist, ethno-cultural, residential, and welfarist (see Carmel \& Sojka, 2020). It is suggested that the normative foundations embedded in different welfare systems lead to dissimilar ways of approaching migrants and migration.
\end{abstract}

\section{Keywords}

European Union; migrants; welfare chauvinism; welfare deservingness; welfare state models

\section{Issue}

This article is part of the issue "Transnational Social Protection: Inclusion for Whom? Theoretical Reflections and Migrant Experiences" edited by Elisabeth Scheibelhofer (University of Vienna), Emma Carmel (University of Bath), and Anna Amelina (University of Cottbus).

(C) 2022 by the author(s); licensee Cogitatio (Lisbon, Portugal). This article is licensed under a Creative Commons Attribution 4.0 International License (CC BY).

\section{Introduction}

Several authors have remarked on the fact that different types of welfare states are loaded with different normative ideas on justice and fairness, and ultimately also on who is considered to be "deserving" of welfare. Literature on "deservingness" (Jeene et al., 2014; Jørgensen \& Thomsen, 2016; Schneider \& Ingram, 2005) have been considering ideological assumptions about who does (and does not) deserve access to welfare. However, authors have not been focused on the interconnections of welfare state models and the idea of deservingness. There has been some research on the differences between the US and Europe in terms of who is considered to be deserving of welfare, but few stud- ies have explored how different welfare state models in Europe might influence ideas on migrants' "deservingness" (see Eggebø, 2010; Jeene et al., 2014). Our article fills this existing gap by exploring how different welfare state models might impact the arguments used to either advocate for or appeal to migrants' deservingness of welfare. We also explore the reasons as to why such arguments might have come about.

This article draws on an earlier one by Carmel and Sojka (2020) where the authors distinguished four different models of "belonging" for migrants. Our research was motivated by a lack of complexity in our current understanding of (migrant) welfare deservingness and its focus on conditions for accessing social welfare that are applied to various migrant categories in 
different European countries. For instance, migrants can be denied welfare benefits based on their ethnicity or their lack of contributions to the welfare system. There are, however, important questions to be explored in connection to the complexity of migrant inclusion and its connection to welfare provision, one of them being: Can welfare state models affect which arguments are used to support or deny a migrant's access to welfare?

Our article draws on empirical data gathered in the UK, Sweden, Poland, Germany, Austria, Hungary, Bulgaria, and Estonia in 2015 and 2016 as part of the NORFACE-funded TRANSWEL project. The data used in this article is mainly based on 50 expert interviews. The article will explore the relationship between four various types of discourses on welfare deservingness for migrants in three different types of welfare states: social democratic (Sweden), liberal (UK, Estonia, Bulgaria, Hungary), and conservative-corporatist (Austria, Germany, Poland).

\section{Welfare State Models, Rationales of Belonging, and Deservingness}

The article draws on the idea that welfare state models contain ideological premises but also, over time, begin to reproduce them. A simple example is whether individual effort is seen to determine income: If so, low redistribution and low taxes are preferred; but if income is seen as more dependent on luck, birth, connection and corruption, higher taxes and potentially progressive, income tax is to be preferred (Alesina et al., 2001). This article suggests that the same kind of normative and ideological assumptions embedded in welfare state models can influence whether migrants are seen to be deserving of benefits or not. Unlike the connection between, for instance, whether unemployed people are seen as deserving of welfare access in different welfare regimes, exploring the interconnections between welfare state models and migration is, however, slightly more complex. Several articles have focused on the topic of moral assumptions behind migrant welfare deservingness (see Greve, 2019, Kootstra, 2016), but the connection between welfare state models and how different ways to define migrant welfare deservingness are connected is not well explored. Instead of seeing deservingness as a binary concept, distinguishing between deserving and undeserving, we intend to explore the versatility of discourses on migrant welfare deservingness and its relation to welfare states. The current literature has not suggested a way to operationalize different discourses on migrant welfare deservingness; rather it is pointed out that there exist multiple exclusionary practices (see Sales, 2002). Thus, we offer an exploratory framework for the connection between these different discourses on deservingness and welfare state models.

Welfare regimes are typically categorised by their key characteristics, such as percentage rate of taxation, degree of income redistribution, and level of expenditure on social protection. The academic policy focuses on access to social security that creates inclusion/exclusion. Traditionally the welfare regimes across various states were classified into three main categories: liberal (e.g., USA), conservative-corporatist (e.g., Germany), and social democratic (e.g., Sweden; EspingAndersen, 1990). This model has, however, received significant critique over the last decades (see Aidukaite, 2004; Cerami \& Vanhuysse, 2009).

Existing criticism of the Esping-Andersen (1990) model resulted in various innovations and more nuanced classification of welfare regimes, some of which focused on welfare states and migrant welfare deservingness for welfare. For example, de Koster et al. (2013) pointed out that exclusionary attitudes towards migrants differ depending on the type of welfare state and can be explained through income inequality in these countries. Others (Keskinen, 2016) suggested that "welfare chauvinism" might be an umbrella term, describing different kinds of exclusionary attitudes directed towards migrants. Carmel and Sojka (2020) distinguished between four different discourses on welfare deservingness for migrants: ethno-cultural, labourist, welfarist, and temporal-territorial ideas of belonging. The central premise of this distinction is that ideas on welfare deservingness for migrants take different forms and should not be unified under a singular term (like welfare chauvinism). Additionally, as concepts, both "welfare chauvinism" and "deservingness" lack in theoretical basis and are often used as an umbrella term to present populist ideas surrounding social welfare (Greve, 2019) such as migrants' access to social security rights (Carmel \& Sojka, 2020). As a result, we know little about, for instance, how deservingness is earned and lost, what kind of (emotional) arguments result in different ideas on deservingness, and how these arguments are applied on a policy level.

The studies that explore the interconnections between migrant welfare deservingness and welfare state models are still in their infancy. Although migrant welfare deservingness has been discussed from a multitude of angles, disciplines, and contexts for decades, and there is a vast body of literature on the topic, including extensive conceptual and empirical works on exclusionary practices, we claim that there is no operationalization as to how welfare state models might influence the versatile practices of exclusion, seeing as deservingness has been seen from a rather narrow angle so far. Most literature focusing on migrant welfare deservingness has not deeply engaged with the issue. Furthermore, as migrant welfare deservingness has been seen from a rather limited angle (see Carmel \& Sojka, 2020; Keskinen, 2016), the studies which do touch upon this interconnection are potentially excluding the versatility of exclusive practices directed towards migrants (see van Oorschot, 2006). What we mean by the previous statement is that, whereas various articles describe the ways migrants are being included in welfare systems, there lacks a 
coherent system to describe all these practices under one umbrella. Our article departs from such categorization, as presented by Carmel and Sojka (2020), and is, therefore, able to explore the interlinkages of exclusionary discourses towards migrants and welfare state models in a systematic manner. Moreover, most studies that have looked at welfare deservingness to this degree have focused on public opinion; few have touched upon the political sphere and how policy discourses on migrant welfare deservingness are created (for exceptions see Kallio \& Kouvo, 2015). As such, this article has the benefit of including a large number of expert interviews. This makes it possible to probe deeper into how policy discourses on migrants' access to welfare are created and if and how these might be inspired by general ideas of fairness, redistribution, etc., in their respective societies. In the following sections we will offer a short introduction to the three welfare state models presented by Esping-Andersen (1990) as well as to the rationales of belonging used by Carmel and Sojka (2020).

\section{Welfare State Models by Esping-Andersen}

In this section we will pick up the three welfare state models presented by Esping-Andersen (1990) and their particularities. The central idea presented by Esping-Andersen is that welfare states can be clustered based on the institutional arrangements, rules, and understandings that guide social policy decisions. Present social policy decisions are hence seen as taking place within frameworks of historical institutionalization. Of central importance in Esping-Andersen's division is the degree of decommodification and the kind of stratification it produces in society.

Esping-Andersen distinguishes between three different welfare state models: liberal, conservativecorporatist, and social-democratic. A Liberal welfare state is characterized by means-tested assistance, modest universal transfers, or social insurance plans. There is little redistribution of incomes in this type. The conservative-corporatist welfare state is characterized by a moderate level of decommodification. Furthermore, there is a heavy emphasis on encouraging full-time motherhood and participation of women with children in the labour market is discouraged. Finally, a social democratic welfare state is highly decommodified. This state is characterised by generous universal and redistributive benefits which do not depend on individual contributions. The classic distinction between these various welfare state regimes is often reflected in how they organise, condition, and set limits to the acquisition of social security benefits by migrants. The rights of migrants and their access to social security are shaped by the politics and governance of migration on the one hand, and the politics and governance of welfare on the other. At the same time, governing migration practices depend on (and are reproduced by) political discourse. Therefore, in exploring the conditionalities that govern migrants' access to social benefits, and associated political discourses, we can throw light on existing typologies of welfare regimes.

Esping-Andersen did not include Central and Eastern European countries in his research and thus their classification within his categorization of welfare states is problematic. McMenamin (2003), for example, classifies welfare systems in Central and Eastern European countries as the East-Central European welfare state model in addition to Esping-Andersen's social-democratic, liberal, and conservative models. Aidukaite (2009, p. 39) argues that "post-communist" welfare system typology shares commonality even though Central and Eastern European countries demonstrate diversity regarding how they solve social policy issues, e.g., "supremacy of the social insurance system, high coverage, but relatively low benefit levels and the identification of the social security systems with the experience of the Soviet past, can be attributed to the post-communist welfare regime." Others however pointed out that all of the Central and Eastern European welfare states vary, and classification of them within one model is incorrect (Becerra-Alonso et al., 2016; Fenger, 2007), as post-communist counters are marked by various patterns of welfare policies. Therefore, categorising welfare states as "post-communist" is limited and based mostly on the historical past of those countries rather than on the construction of their current welfare states. All types of categorization of welfare states have their limitations. There is a lack of coherent categorization which would allow making sense of migrant exclusionary practices instead of describing them in a rather separated manner in particular. Consequently, regardless of the problems which Esping-Andersen's categorization produces, we have decided to follow his classical model as a base for our analysis.

\section{Discourses of Migrant Welfare Deservingness}

Carmel and Sojka (2020) have suggested that the current way of describing ideas which govern migrants' social rights are insufficient. They distinguish between two paradigms - the literature on welfare chauvinism and research on migrant welfare deservingness-and propose "four distinct 'rationales of belonging' that mark out the terms and practices of social membership, as well as relative positions of privilege and subordination" (Carmel \& Sojka, 2020, p. 645). These rationales of belonging are temporal-territorial, ethnocultural, labourist, and welfarist. Ethno-cultural belonging describes a discourse present in most welfare chauvinist arguments where access to social rights is seen to be connected to ethnic belonging. Migrants in this discourse are presented as "others" and ineligible for social benefits because of their ethnic background. Labourist belonging has certain similarities with jus domicilis, which refers to gaining citizenship by stating that one has set up a permanent home and taken up work in 
the country. The relevance of having employment is at the centre of this idea as people unable to engage in active labour are seen as undeserving of welfare. Temporal-territorial belonging centres around equalising nation and nation-state by assuming a sedentary presence from one that is eligible for welfare benefits. The relevance of certain time criteria which people must spend in the country is at the centre for defining their deservingness of social welfare in this rationale. Welfarist belonging centres around participating in the welfare state. Welfare and national identity become intertwined as good "nationals" are expected to contribute to sustaining the welfare state. Therefore, one is seen as undeserving if one does not contribute to the welfare state. Carmel and Sojka (2020, p. 1) suggest that these rationales of belonging do not exist in isolation but qualify each other in ways that imply different politics and governance of migrants' rights. Governing migration practices depend on (and are reproduced by) political discourse. Therefore, exploring political discourse on migrants' access to social welfare assists in the classification of welfare regimes. Furthermore, the authors add that each country can have multiple competing rationales of belonging, but also clarify that there is usually one that is dominant. Therefore we have in this article departed only from the notion of the dominant rationale of belonging.

\section{Research Context, Design, and Methodology}

This material is drawn from data collected during the research project TRANSWEL (Mobile Welfare in a Transnational Europe: An Analysis of Portability Regimes of Social Security Rights), which examines mobile EU citizens' access to social security rights in the EU. Our analysis rests on 50 in-depth interviews with experts in eight countries (Austria, Bulgaria, Estonia, Germany, Hungary, UK, Poland, and Sweden). The research teams interviewed 50 policy experts, officials from ministries, policy advisors, and senior legal experts to gain insight into their interpretations, experiences, and understandings of the EU regulation of social security rights of mobile EU citizens and its intersection with their national context. The selection criteria for participants was policy relevance, seniority and, of course, availability. It was decided to maintain the anonymity of all participants to encourage openness and a higher degree of trust between the participant and interviewer in each case. We asked experts to reflect upon the relationship between mobility and the regulation of social rights in their country, as well as their interpretation of the nature of the wider institutional, political, and social context within which the relationship between mobility and the portability of social rights is framed. Participants were also asked about the characteristics and purposes of any reforms, recent or proposed.

Given the specificity of our policy domain, with its small number of specialist experts across the EU, and with regard to the contentious and, in some cases, politicised nature of the subject matter of the interviews, our participants' potential reputational vulnerability seemed both particularly important and, in some cases, possibly difficult to protect. Therefore, to avoid inadvertently revealing participants' identities through descriptions of their institutional role we asked them to offer descriptions of their role in this policy field.

All interviews were performed in the native languages of the experts. The recordings were transcribed in native languages as well, respectively, with transcription being a first step in the qualitative data analysis, as it involves ad hoc judgements and reflections on what has been transcribed. In other words, the transcribing process involved the close observation of data through repeated careful listening. The expert interviews were analysed using small-scale interpretive analysis (Clark et al., 2021). We have chosen small-scale interpretive analysis to support and achieve the depth of case-oriented welfare states classification. As argued elsewhere, "in the EU itself, social security co-ordination is considered a highly specialist "technical" field, and this constitutes a small, expert and elite population with very limited heterogeneity" (Carmel \& Sojka, 2020, p. 653). Hence, the relatively small overall number of interviewees per country. Within this frame of reference, our sample holds, what Malterud et al. (2016, p. 1760) refer to as "information power" when "sample adequacy, data quality, and variability of relevant events are often more important than the number of participants." This article is based on the authors' own analysis of interviews with the policy experts. The next section presents our small-scale interpretive analysis of expert interviews.

\section{The Connection Between Welfare State Models and Discourses on Migrant Welfare Deservingness}

Our analysis of discourses on the governance of migrants, which are presented in subsequent sections, allowed us to observe the interrelations between welfare state models and the discourses on deservingness (Table 1).

What we can see from the table above is that there are certain patterns to be observed in terms of the relationship between welfare state model and the model of migrant welfare deservingness based on our limited data. Firstly, countries with liberal welfare state models tend to either follow the labourist or welfarist model of migrant governance. Secondly, countries with conservative-corporatist welfare state models tend to resort to the ethno-cultural model of deservingness and governance. Finally, since this data only contains one state with the social-democratic model, it is difficult to reach a conclusion; however, the temporal-territorial model was preferred in the Swedish case. Going back to our initial idea, namely the argument that welfare state models contain hidden normative assumptions on justice and deservingness which influence if and which kinds of migrants are seen to be deserving, we will now 
Table 1. Interrelations between welfare state models and the discourses on deservingness (based on expert interviews).

\begin{tabular}{lll}
\hline & Welfare state model & Discursive model of migrant governance/deservingness \\
\hline Estonia & Liberal & Labourist \\
Bulgaria & Liberal & Labourist \\
UK & Liberal & Welfarist \\
Hungary & Liberal & Welfarist \\
Poland & Conservative-corporatist & Ethno-cultural \\
Germany & Conservative-corporatist & Ethno-cultural \\
Austria & Conservative-corporatist & Ethno-cultural \\
Sweden & Social-democratic & Temporal-territorial \\
\hline
\end{tabular}

explore how or why there might be such connection observed between the two. In the following section we will go into how we have categorized the countries and what the potential reasons behind these connections could be. Initially, we will provide some quotes from expert interviews and thereafter an analysis as to why these countries might have adopted the particular discourse on deservingness.

\section{Liberal Welfare State and Labourist Discourse of Deservingness}

Two countries that were liberal and seemed to tend towards the labourist discourse on deservingness are Estonia and Bulgaria. As mentioned, labourist discourse on deservingness could be related to the prevalent emphasis on working. One of the examples of such discourse is the following quote from an Estonian expert:

Our workforce is going away. We are schooling workforce and it is going away, and then we are not even getting family benefits. We have to educate these children; schools and everything have to be provided by us and we are not getting the taxes from this one person. On one hand, yes, these are our children so why should someone else pay, but then again the mother of a child is not working and the father is getting his salary in another state, but we have contributed so that he could earn [entitlement] there. I think that UK's economy has won a lot from having all the Polish people there.

The focus of this interviewee is clearly on seeing citizens as workers and the problems of the potential workforce leaving Estonia while not contributing to the local taxes. This is a rather intrinsic view on the population of the country, mostly seeing them as taxpayers without emotional arguments, as opposed to an ethno-cultural view as we see later.

Estonia has been following quite liberal policy ever since the collapse of the Soviet Union (Bohle \& Greskovits, 2007). Most of the focus has been on reviving the economy and there is a strong normative idea that, once a country's economy is doing well, other problems will naturally resolve. Even though the welfare system of the country is a mix of social-democratic ideas from Nordic countries, the general value-laden drive seems to be towards neoliberal ideas (Fröhlig et al., 2016). For instance, even though they have long parental leave, sick insurance is tightly connected with whether one is working or not. Furthermore, during the economic crisis, Estonia was lifted up by IMF as a prime example of austerity policy, where social benefits were cut and the labour market was further liberalized for the sake of remaining debt-free. Nevertheless, it should be noted that Estonian political ideology has, during recent years, shifted slightly from extreme neoliberalism to a more mixed model.

In terms of migration governance, this attitude translates itself to the labourist ideals, following a rather utilitarian view of migrants as expressed by experts, both international and Estonian. Namely, migrants are viewed as a resource as long as they benefit the country's workforce. To this day the social welfare in the country is rather meagre, but the rather low costs of living compared to high salaries for highly skilled professionals are making it an increasingly attractive country for migrants. Especially highly skilled migrants are seen as a resource, providing for the country's economy. As such these migrants are perceived as less dependent on social welfare.

Bulgaria could also be considered to be a liberal welfare state which has adapted labourist discourse on deservingness. It is characterised by "post-communist" welfare (Cerami \& Vanhuysse, 2009), dominated by contributory social insurance with wide coverage but low levels of benefits, including health and family benefits, and with a three-pillar pension system. In terms of deservingness, Bulgaria could be classified as an ethno-cultural country, as Bulgarian experts repeatedly emphasized "problematic" Roma Bulgarians in Germany putting all Bulgarians under an unfavorable light, namely as being "lazy," welfare-dependent, and not willing to work. The work ethic, therefore, was deeply ingrained in the ways Bulgarian experts perceived deservingness to welfare. Similarly, Bulgarian migrants who had moved abroad and been successful were highly 
esteemed. This sentiment very much echoes the attitude of Estonian experts who also talked highly of Estonian migrants abroad.

In general, both countries put a high significance on appearing as hard-working people to the rest of Europe and criticized groups in their society that were unemployed. These groups were seen as violating the rules of fairness. Interestingly, the focus was, however, not on these groups' failure to contribute to the welfare state, but rather on their strong work ethic, which was perceived as virtue in itself.

\section{Liberal Welfare State and Welfarist Discourse of Deservingness}

Similarly, two liberal welfare states could be categorised as having opted for a welfarist discourse of deservingness: UK and Hungary. Welfarist discourse brings attention to the contributions for welfare as a basis of deservingness. The welfarist discourse could be exemplified with the UK case, where references to "benefit tourism" were taken up by experts:

This issue of...paying child benefit...is kind of, I think...is in the Treasury report....My take is [that] this was talked between the member states and the Commission for, like, quite a few years, I guess since all of the A8 migration in 2004, so I guess lots of Polish plumbers [migrants] - to be stereotypical[are] getting child benefit for their children back in Poland....And then suddenly [this] becomes part of the...conservative party manifesto [to refuse welfare security benefits to migrants].

The issue of porting social benefits is taken up by this expert as they are speaking of "Polish plumbers" exporting their child benefits to Poland. This phenomenon was spoken about by several British experts and seen as problematic for sustaining fairness. While working and contributing to the UK system, the families of Polish plumbers were seen as "unworthy" of the benefit because they were not part of the UK's welfare system. EU regulations that allowed for such a settlement were presented by experts as being seen as problematic by the wider public in the UK.

The British welfare state is characterised as liberal with means-tested benefits, low levels of contributory benefits, universal services and oriented to safety net provision. Migrants' access to social security is surrounded by political questions and debates around welfare chauvinism and the assumption that the British welfare system needs to be protected against migrants who come to claim benefits (Carmel \& Sojka, 2018). Consequently, the assumption of benefit truism exposed the welfarist nature of the British welfare state. In the case of Poland, residential conditions were more important, but there were also high levels of conditionality concerning work, which includes income and type of con- tract, both of which act as informal barriers. The impact of the 2004 enlargement on migration to the UK, particularly concerning welfare, has featured heavily in public and political discourse in the UK. Since 2013, the UK Government and its predecessor have introduced seven significant regulatory changes under the broad heading of "restricting access to benefits" for EU migrants. The political context for these developments is the UK's referendum on EU membership and the relatively high conditions for eligibility, which are typically associated with social security in the UK. Interviewed British experts spoke of reform as being one of "fairness" between EU member states and between long and short-term UK residents. Carmel and Sojka (2019) found that the dominant rationale of belonging found in British experts' discourse was welfarist, with emphasis put on ethicised protection of welfare and public service resources.

Similarly, the idea of having to contribute to the system runs deep in discourses presented by Hungarian experts. On one hand, there was a strong reactionalist attitude towards Western countries allegations of Hungarian migrants "taking advantage of their system." On the other hand, interestingly, there was also a strong dislike towards Hungarian migrants that lived in Hungary but worked in Austria. These migrants were seen as taking advantage of both systems and, to a degree, being disloyal to the Hungarian welfare system by paying their taxes in Austria. Whereas there have been many discussions on the ethno-centrist sentiments in Hungary, there are some other illustrations of the same kind of welfarist attitude as Hungary held for quite a long time a program called Hungarian Residency Bond, whereby it was possible to obtain Hungarian citizenship by investment. This also shows a very calculated approach to migration, mostly seeing potential migrants as beneficiaries of the state. There are however ongoing changes happening in Hungarian society and as the study was made in 2015-2016, one might suggest that the model of deservingness could have shifted through that time towards a more ethno-cultural approach.

Both Hungary and the UK emphasised the relevance of their residents contributing to the existing welfare system. Both exporting benefits, as well as working and residing in different countries, were deemed as unfair. The welfarist attitude, in this case, does have a connection with the dominant ideology in liberal welfare state thinking, where citizens are seen as individually responsible for their wellbeing and also considered by the state, not as potentially in need of help, but rather as potentially abusing the system for their own benefit.

\section{Conservative-Corporatist Welfare State and Ethno-Cultural Discourse of Deservingness}

All conservative-corporatist countries could be classed as having adopted ethno-cultural discourse of deservingness. Ethno-cultural discourses stress the importance of ethnicity for "deservingness." As an example of 
ethno-cultural discourse on deservingness, we refer to the interview with a Polish expert, who stated:

The good characteristic of immigration is that Ukrainians are relatively close to us in terms of-and here I will use all politically incorrect words-race, faith, religion.....Let's say that they will be brother Ukrainians, we will not have racial issues, most probably we will not have religious problems, as they are Christian.

This quote illustrates how Ukrainian workers in Poland were seen as less problematic than groups such as refugees because they were perceived ethnically closer to the "native" population. The ideal solution presented by experts, however, was the Polish population not migrating but accepting Ukrainians as part of the workforce as "the next best" option.

Countries that could be defined as both conservativecorporatist and having adopted ethno-cultural discourse on deservingness are Austria, Germany and Poland. The Polish social security system is characterised by "post-communist" welfare (Cerami \& Vanhuysse, 2009) dominated by contribution-based benefits, with wide coverage but low levels of benefit, a universal health system, and a three-pillar pension system. In the 1990s Polish welfare state shifted from a communist welfare state to a post-communist welfare state (Cerami, 2006), and today the Polish welfare system remains under the influence of political and economic transition to capitalism (Inglot, 2008) and pos-EU-accession changes (Rae, 2015). The Polish social security system covers all people in active employment and their family members, as well as those who are registered as unemployed. All individuals in active employment, such as employees, the selfemployed and farmers, are covered by mandatory insurance which would suggest that the discursive emphasis should be put on work (similarly to the Estonian and Swedish cases) but it is not. Discourses on who deserves access to social security rights presented in this article are what Carmel and Sojka (2019) referred to as ethno-cultural rationale, which focuses on gendered expectations of ethnonational loyalty, identity, and culture. In other words, formal and informal conditions, barriers to accessing social security rights (Carmel et al., 2020) for migrants and residential conditions are more important. There are high levels of conditionality in relation to work, including income and type of work contract, that act as informal barriers; in discourse, however, emphasis is placed on ethno-cultural arguments for/against deservingness.

Germany is a federal state and its social security system was historically dominated by contributory social insurance, supplemented by means-tested social support with an insurance-based health system involving multiple healthcare providers. Reforms have introduced market mechanisms in health and pensions, increased conditions and discretion in unemployment benefits, and increased focus on mothers' employment in family benefits. The German welfare state is often classified as conservative-corporatist (Carmel \& Papadopoulos, 2016) with contributory-based benefits and services dependant on employment and occupations, and a strong emphasis on maintaining income at vulnerable times, such as unemployment. The focus of German experts regarding EU free mobility was emphasising the importance of "no borders," but there were also strong ideas of EU migrants eventually returning to their home countries. As such, this attitude does not much differ from the policy towards "guest workers" in the 1960s, where these migrants were also seen as residing in Germany temporarily. There were no strong fears expressed by German experts about EU free movers abusing the system; the main idea was rather that these migrants do not belong to their society because "they will eventually go back." As such, this attitude can be largely seen as an ethno-cultural way of belonging where migrants, even if they are working and contributing to the welfare system and have resided in the country for some time, are still considered temporary.

Finally, Carmel and Papadopoulos (2016) classify the Austrian welfare state as conservative-corporatist, featuring contributory-based benefits and services, being dependant on employment and occupations, and maintaining income at vulnerable times with the emphasis on supporting families with children. In terms of the discourses of "deservingness" towards migrants, Austria could be considered as a mix between ethno-cultural belonging and welfarist belonging. Discursively, Austrian experts' focus on the protection of the Austrian welfare state that should prioritise Austrian citizens (Runfors et al., 2021) as it can be potentially abused by EU mobile citizens from less wealthy countries, such as Hungary. Furthermore, there was a high consciousness among Austrian experts regarding prevalent national policies above EU policies, as the latter focuses on mobile EU citizens; this led us to classify the Austrian discursive model of migrant governance/deservingness as ethno-cultural in nature.

All three different conservative-corporatist states showed their inclination towards the ethno-cultural model of deserving in dissimilar ways. For instance, German experts were treating EU free movers as temporary and there was an implicit assumption that these migrants would eventually return home. Austrian experts, on the other hand, did not directly speak of migrants as problematic but they referred to "EU free movers" during political debates. Thus, an indirect connection between increasing conservatism and nationalism and migration was made; which to a degree legitimated the reactions of the conservative wing. Finally, there was a strong narrative of needing to defend the Polish nation against extinction in the interviews with Polish experts. This shows how ethno-cultural discourse on deservingness can take various shapes. The strong emphasis on family, and seeing the nation as a family, 
is prevalent in the conservative-corporatist welfare state model. It might not be that surprising, therefore, that all these states had adopted an ethno-cultural way of defining deservingness.

\section{The Social-Democratic Welfare State and Temporal-Territorial Discourse of Deservingness}

Finally, only one state in our sample presents both the social-democratic welfare state model and temporalterritorial discourse on deservingness. Temporalterritorial discourse refers to the idea that all people residing in the country should be seen as deserving of welfare. The focus in the interviews with Swedish experts concerning the social protection of EU migrants was on the personal identification number (PIN) system. A PIN limits access to social protection to a certain period spent in the country, for instance through the condition of EU migrants having to have at least a one-year working contract. The power of the PIN being connected to a certain amount of time is described by one expert as follows:

[You] get a personal identity number...you are part of the social security agency...you are...register[ed] at the Taxes Board Agency [and] can open a bank account...rent a video....buy a gym membership....You can get to the county council and get health care....Everything just functions....You just say the magic number and all doors open up.

The expert is describing the importance of the PIN, not only for accessing social protection in Sweden but to earn a right to all kinds of different services that indirectly become connected to residency. Swedish experts in general were assuming the irreplaceability of PIN even if they were critical of the number. However, arguments such as "residency requirement" were also expressed by the interviewees as a means to defend the generous Swedish welfare state from abuse. Much of the experts' discourse also focused on treating people as equals, which was seen as achievable only through residency. Furthermore, strong state interests emerged in experts' presentation of outmigration as a problem-because "Swedish people should apply for jobs in the Swedish labour market."

The connection between social-democratic welfare state models and temporal territorial discourse of belonging could be explained by the strong emphasis on universal welfare which was the basis of social-democratic countries. This universal welfare was, however, grounded on the idea of a sedentary population (see Schierup \& Ålund, 2011). These connotations could be observed in the Swedish case, for instance from the campaign "Folkhemmet" (People's Home) driven by a socialdemocratic party in the 1960s. Whereas this program made a point about redistribution and grounded the idea of fairness to "everyone" being equal, it also treated population as homogenous and hardly had any room for acknowledging the presence of migrants, even though work migration was high already in the 1960s (Keskinen et al., 2016). As mentioned, the current policy in Sweden relies highly on people being sedentary despite some new developments. Rules such as the one-year work contract requirement to obtain a PIN make it clear that Sweden follows the model of deservingness where, to be eligible for welfare, one needs to first prove oneself as a steady member of society (Fröhlig et al., 2016). The system, therefore, is protective in different ways to most other countries in our data, presenting a high threshold for entering the country. The idea of fairness, therefore, relies heavily on the notion of being part of the society and more subtly also having adopted certain norms on what it means to be part of Swedish society.

It is difficult to make broader conclusions on the connection between social-democratic welfare state models and temporal-territorial discourse on deservingness since the data consists of only one country. It could be suggested that social-democratic countries might either opt for temporal-territorial discourse on deservingness or welfarist discourse. The latter has been observed as playing a key role in Finland, also a social-democratic welfare state, as observed by Keskinen (2016). In general, social-democratic states have built up a rather generous welfare system that puts high emphasis on needs-based benefits but requires a way to monitor who is eligible for these kinds of general benefits and on what grounds. Ideas of fairness, in this case, are connected to making sure that those receiving help are indeed eligible via monitorisation. In the Swedish case, eligibility is earned by proving a certain connection to the country, i.e., by having spent enough time there (Runfors et al., 2016). In the case of EU free movers, that however meant that many of them were considered as undeserving because of their high mobility. Furthermore, there was also an emphasis on providing firsthand jobs for the Swedish population, and only thereafter to "foreigners."

\section{Conclusion}

Not much has been written on the topic of how and if welfare state models might influence how migrants' welfare deservingness is being perceived in different European countries. Thus, this article is exploratory in nature and it does show, based on the sampled countries, that there are certain connections, namely: that liberal welfare states opt for either welfarist or labourist models, that conservative-corporatist states chose ethno-cultural models, and that only the social-democratic country preferred temporal-territorial model. The question is, however, how can that connection be explained.

Liberal states put high importance on individual achievement and, as mentioned, consider it to be the result of personal effort. Migrants in that context are to be seen in a similar vein, as people who need to prove their deservingness through either having work (labourist model of deservingness) or through contributing to the system (welfarist model of deservingness). 
In this respect, migrants are treated the way the majority population is seen, so false ideas of their contributions or employment might prevail (see Ehata \& Seeleib-Kaiser, 2017; Kremer, 2016). Nevertheless, the derogatory attitudes towards migrants are mostly explained through their assumed unwillingness to either work or contribute to the welfare system.

Secondly, conservative-corporatist countries in our sample all preferred the ethno-cultural model of inclusion. This in itself is not a surprising result, as the core idea in conservative-corporatist welfare state relies on the notion of "state as a family." Ideas of family as a social security net, instead of state, remain prevalent in these countries; however, how a family is defined can be quite ethnically loaded. Strong family values supported in these states seem to also coincide with the idea of an "alien population" that is not part of the family. This idea is very well illustrated by the Aussiedler policy in Germany in the 1990s: Migrants from Russia who could successfully prove their German origin were granted access to Germany, whereas many Turkish migrants who had been in the country longer still struggled. The arguments which are used to support strong family values in this case often coincide with primordialist arguments based on ancestry.

There was only one social-democratic country in the sample so more studies need to be made to explore if there is a connection between social-democratic regime and temporal-territorial idea of belonginess. Nevertheless, in the Swedish case, there was a strong connection between the established welfare state and the idea of a sedentary population. Their idea of fairness mostly included all the permanent residents of Sweden excluding Swedish citizens that had moved away. One potential explanation could be that social-democratic models often use residency to define who is deserving and undeserving instead of, for example, employment or contributions. This idea however can both rest on certain ideological assumptions on the relevance of time spent in the country, giving those that have been born in the country a clear advantage, but also reproduce the sentiments against temporary migrants, who are seen as undeserving.

The premise that deservingness or, if you will, welfare chauvinism, can be multi-faceted and does not rely on one criterion is rather new. Therefore, literature on deservingness has not really taken advantage of the studies on the normative ideas that support welfare state models in each country. We suggest that studies on deservingness need to pay closer attention to welfare state ideologies but also uropeze that there are deeply ingrained ideologies in each welfare state that influence which migrant is deserving and which is not.

\section{Acknowledgments}

Research for this article is based on and was funded by the NORFACE Welfare State Futures programme (grant number 462-74-731). The research was developed in the TRANSWEL project Mobile Welfare in a Transnational Europe led by Prof. Anna Amelina. The interviews were collected during Work Package 1 , led by Dr. Emma Carmel, and Work Package 3, led by Prof. Ann Runfors. We are grateful to all policy experts who participated in our research, for their time and consideration in sharing their views and experiences with us.

\section{Conflict of Interests}

The authors declare no conflict of interests.

\section{References}

Aidukaite, J. (2004). The emergence of the post-socialist welfare state: The case of the Baltic states: Estonia, Latvia and Lithuania [Doctoral dissertation, Södertörn University]. Södertörn University Campus Repository.

Aidukaite, J. (2009). Old welfare state theories and new welfare regimes in eastern Europe: Challenges and implications. Communist and Post-Communist Studies, 42(1), 23-39.

Alesina, A. F., Glaeser, E. L., \& Sacerdote, B. (2001). Why doesn't the US have a European-style welfare system? National Bureau of Economic Research Cambridge.

Becerra-Alonso, D., Androniceanu, A., \& Georgescu, I. (2016). Sensitivity and vulnerability of European countries in time of crisis based on a new approach to data clustering and curvilinear analysis. Revista Administratie si Management Public, 2016(27), 46-61.

Bohle, D., \& Greskovits, B. (2007). Neoliberalism, embedded neoliberalism, and neocorporatism: Towards transnational capitalism in Central-Eastern Europe. West European Politics, 30(3), 443-446.

Carmel, E., \& Papadopoulos, T. (2016). Detached, hostile, adaptable and liberalising: The chameleon qualities of the UK's relationship with EU social policy. The Political Quarterly, 87(2), 228-237.

Carmel, E., \& Sojka, B. (2018). Social security and the "management" of migration. In J. Millar (Ed.), Understanding social security: Issues for policy and practice (3rd ed.). Policy Press.

Carmel, E., \& Sojka, B. (2020). Beyond welfare chauvinism and deservingness. Rationales of belonging as a conceptual framework for the politics and governance of migrants' rights. Journal of Social Policy, 50(3), 645-667.

Carmel, E., Sojka, B., \& Papie, K. (2020). Beyond the rights-bearing mobile EU citizen: Governing inequality and privilege in European Union social security. In A. Amelina, E. Carmel, A. Runfors, \& E. Scheibelhofer (Eds.), Boundaries of European social citizenship (pp. 46-72). Routledge.

Cerami, A. (2006). Social policy in Central and Eastern 
Europe: The emergence of a new European welfare regime. LIT Verlag.

Cerami, A., \& Vanhuysse, P. (2009). Post-communist welfare pathways: Theorizing social policy transformations in Central and Eastern Europe. Springer.

Clark, T., Foster, L., Bryman, A., \& Sloan, L. (2021). Social research methods (6th ed.). Oxford University Press.

de Koster, W., Achterberg, P., \& Van der Waal, J. (2013). The new right and the welfare state: The electoral relevance of welfare chauvinism and welfare populism in the Netherlands. International Political Science Review, 34(1), 3-20.

Eggeb $\varnothing$, H. (2010). The problem of dependency: Immigration, gender, and the welfare state. Social Politics, 17(3), 295-322.

Ehata, R., \& Seeleib-Kaiser, M. (2017). Benefit tourism and EU migrant citizens: Real-world experiences. Social Policy Review, 29, 181-197.

Esping-Andersen, G. (1990). The three political economies of the welfare state. International Journal of Sociology, 20(3), 92-123.

Fenger, H. J. M. (2007). Welfare regimes in Central and Eastern Europe: Incorporating postcommunist countries in a welfare regime typology. Contemporary Issues and Ideas in Social Sciences, 3(2), 1-30.

Fröhlig, F., Saar, M., \& Runfors, A. (2016). Swedish and Estonian discourses on free EU movement, welfare and belonging (Working Paper 3/2016). Welfare State Futures. https://welfarestatefutures.files. wordpress.com/2018/02/wsf-working-papertranswel-3-2016-web.pdf

Greve, B. (2019). Welfare, populism and welfare chauvinism. Policy Press.

Jeene, M., van Oorschot, W., \& Uunk, W. (2014). The dynamics of welfare opinions in changing economic, institutional and political contexts: An empirical analysis of Dutch deservingness opinions, 1975-2006. Social Indicators Research, 115(2), 731-749.

Inglot, T. (2008). Welfare states in East Central Europe, 1919-2004. Cambridge University Press.

Jørgensen, M. B., \& Thomsen, T. L. (2016). Deservingness in the Danish context: Welfare chauvinism in times of crisis. Critical Social Policy, 36(3), 330-351.

Kallio, J., \& Kouvo, A. (2015). Street-level bureaucrats' and the general public's deservingness perceptions of social assistance recipients in Finland. Social Policy \& Administration, 49(3), 316-334.
Keskinen, S. (2016). From welfare nationalism to welfare chauvinism: Economic rhetoric, the welfare state and changing asylum policies in Finland. Critical Social Policy, 36(3), 352-370.

Keskinen, S., Norocel, O. C., \& Jørgensen, M. B. (2016). The politics and policies of welfare chauvinism under the economic crisis. Critical Social Policy, 36(3), 321-329.

Kootstra, A. (2016). Deserving and undeserving welfare claimants in Britain and the Netherlands: Examining the role of ethnicity and migration status using a vignette experiment. European Sociological Review, 32(3), 325-338.

Kremer, M. (2016). Earned citizenship: Labour migrants' views on the welfare state. Journal of Social Policy, 45(3), 395-415.

Malterud, K., Siersma, V. D., \& Guassora, A. D. (2016). Sample size in qualitative interview studies: Guided by information power. Qualitative Health Research, 26(13), 1753-1760. https://doi.org/10.1177/10497 32315617444

McMenamin, I. (2003). Is there an East-Central European variety of democratic capitalism? A twentytwo-country cluster analysis (Working Paper No. 3). School of Law and Government, Dublin City University. https://doras.dcu.ie/2119

Runfors, A., Saar, M., \& Fröhlig, F. (2021). Policy experts negotiating popular fantasies of "benefit tourism" policy discourses on deservingness and their relation to welfare chauvinism. Journal of Immigrant \& Refugee Studies. Advance online publication. https:// doi.org/10.1080/15562948.2021.1933670

Sales, R., (2002). The deserving and the undeserving? Refugees, asylum seekers and welfare in Britain. Critical Social Policy, 22(3). https://doi.org/10.1177\% 2F026101830202200305

Schierup, C.-U., \& Ålund, A. (2011). The end of Swedish exceptionalism? Citizenship, neoliberalism and the politics of exclusion. Race \& Class, 53(1), 45-64.

Schneider, A. L., \& Ingram, H. M. (2005). Deserving and entitled: Social constructions and public policy. SUNY Press.

van Oorschot, W. (2006). Making the difference in social Europe: Deservingness perceptions among citizens of European welfare states. Journal of European Social Policy, 16(1), 23-42.

\section{About the Authors}

Maarja Saar is a lecturer at Jönköping University. Her research has focused on different migration-related topics such as deservingness of migrants, lifestyle migration, and transnational social welfare. Over the years Maarja has taken part of several international projects, including TRANSWEL, which has been the basis of this article.

Bozena Sojka is a research fellow at the Institute for Community Research and Development at the University of Wolverhampton. She has over 10 years of experience in undertaking research on social policy, welfare states, international migration, and governance analysis as a new approach to the interpretation of public policy in a wide range of institutional settings. 
Ann Runfors is associate professor at the School of Historical and Contemporary Studies at Södertörn University. Her fields of research are migration, education, welfare, transnationalism, youth, and ethnographic approaches-with a special focus on issues relating to the structuration of everyday life in a globalised world, social positioning, intertextuality, identification, ethnification, and racialization. 